\title{
EXCURSION TO SOUTHWICK, FULWELL AND ROKER.
}

August $7 \mathrm{TH}, \mathrm{I} 903$.

\author{
Directors: George AbBotT, M.R.C.S., F.G.S., AND \\ D. Woolacott, M.Sc., F.G.S. \\ Excursion Secretary: GeoRge Aвbotr.
}

(Report by The Excursion SECreTari.)

THE party arrived from Berwick about eleven and proceeded, with other members already at Sunderland, to the Southwick old quarry. Sections of the magnesian limestone beds, which, here at any rate, were not cellular, stood like walls of three or four feet in thickness and ten to fifteen feet high on the boundary between this and the Fulwell quarry.

The clean weathered white surface showed the concentric honeycomb structure to perfection although quite solid.

Fulwell quarry was seen on crossing the road at Vainey Hill. The working face here is about roo feet deep, and goes through all the beds down to the lowest magnesia bed (or " marl" bed of the quarrymen). At one place on the surface of the hill a mass of balls and botryoidal masses in a yellow matrix was shown, which the Director considered was on the same horizon as the Roker cannon ball bed, although it is not more than balf the thickness of that stratum, and the balls seldom exceed three inches in diameter. Their fractured surfaces frequently exbibited fine concentric rings about twelve to an inch, which he thought were secondary and due to weathering, similar markings being common wherever these balls get exposed.

Descending into the quarry the following beds were passed over in the order given-" Main Course," "Boulder, Marl and Dunstone," "Flags," "Twenty-inch Marl" (this a valuable datum line all through the quarry) and "Greystone."

The lowest marl bed is undisturbed; it is known to be at least ten feet thick.

Both the spherical and rectangular arrangements of the honeycomb structure were seen in all the stages-according to the Director's suggested explanation of a progressive development or "growth" in the beds." A theory which appears to explain both the multitude of patterns and the diversity of the architecture. It seems probable that it is a case of "orderly arrangement" of calcium carbonate when in an amorphous condition, 
and this occurred after the deposition of the beds. The hundred or more patterns are easily arranged into two chief classes, conveniently termed Honeycomb and Coralloid, each with at least two varieties. Each class has four distinct stages, and both classes began with either parallel or divergent systems of rods. The site of a bed which last year had given abundant Coralloid

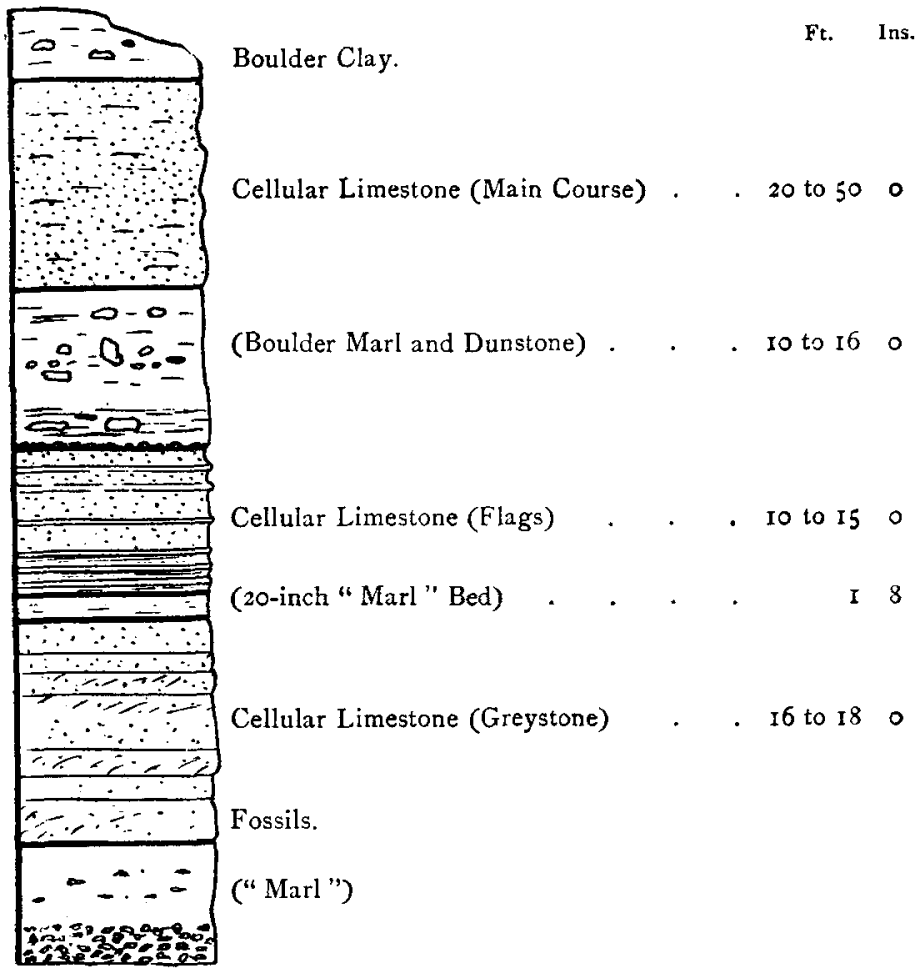

The names in brackets are quarry names.

Fig. I5.-Section at Fulwell Hill Quarry.

specimens was shown, but the same bed as now exposed consists only of thick rod clusters pointing more or less downwards. The so-called " marl," which consists of about equal parts Magnesium Carbonate and Calcium Carbonate, forms three distinct beds and also fills the interstices of the cellular limestone. There are plenty of concretionary botryoidal masses in these beds, some even three feet in diameter, but these exhibit no cellular (honeycomb or coralloid) structure. These masses are, however, 
frequently hollow and are free from marl, so that probably the cavities were once filled with crystals of salt or other alkali.

Sufficient specimens having been collected, Dr. Woolacott described the relations of the Raised Beach containing blocks of magnesian limestone as well as stones from the Cheviots. On the way to Roker a section of oolitic magnesian limestone in Cemetery Lane was examined, some of it being vesicular. The cannon ball bed was viewed from end to end. Here too the secondary banding in the balls of the cliff was very noticeable. The Excursion finished by the party passing through the caves in the soft yellow limestone bed under which the cannon ball bed dips. In the evening Dr Woolacott very kindly gave at the Sunderland Library a description of the geological features of the district illustrated by lantern photographs.

\title{
EXCURSION TO CLAXHEUGH.
}

\author{
August 8Th, I9०3. \\ Director: D. WoolacotT, M.Sc., F.G.S.
}

(Report by The Director).

ThE first point of interest on this excursion was the Ford Quarry, where the best fossiliferous exposure of the Permian in the North of England occurs. The search for fossils was soon rewarded by a good series of Middle Magnesian Limestone specimens. The small party then moved on towards the Claxheugh section, the principal physiographical features of the district being pointed out on the way by the Director. This section has been described by the Director (see references below). The Coal Measures, yellow sands, marl and slate, and the Lower and Middle Magnesian Limestone, are all exposed here with complications which render the section especially interesting.

When the Claxheugh section had been examined, the party walked back along the banks of the Wear into Sunderland, and although it had been raining for the greater part of the day, the excursion was a thoroughly enjoyable one.

\section{REFERENCES.}

Geological Survey Map, I05, S.E.

I835. SEDGWICK, Prof.- "Internal Structure of the Magnesian Limestone." Trans. of Geol. Soc. (Lond.), and Series, vol. iii.

I848. IBID.- "Catalogue of the Fossils of the Permian System." Ibid, vol. i.

I854. HowsE, R.-" Notes on the Permian System of Northumberland and Durham" Tyneside Nat. Field Club Reports, vol. iii.

1866. KIRBY, J. W.- "Fossils of Marl Slate and Magnesian Limestone." Northumberland and Durham Nat. Hist. Trans, vol. i, p. 184. 